\title{
HISTORY ON TRIAL: HISTORICAL NARRATIVE PLURALISM WITHIN AND BEYOND INTERNATIONAL CRIMINAL COURTS
}

\author{
BARRIE SANDER*
}

\begin{abstract}
With the resurgence of the field of international criminal justice in recent decades, expectations have increasingly been placed on international criminal courts to construct consistent and authoritative historical narratives about the mass atrocity situations that fall within their purview. Taking this expectation as its focus, this article seeks to illuminate the historical narrative pluralism that can arise both within and beyond the international criminal courtroom. Within the courtroom, two types of narrative pluralism are identified: first, inter-court narrative pluralism, which arises when different courts examine the same mass atrocity situation from different perspectives; and second, intra-court narrative pluralism, which emerges when narratives constructed within an international criminal judgment are revisited in later cases adjudicated by the same court. Beyond the courtroom, it is contended that even when international criminal courts manage to achieve inter-court and intra-court narrative consistency, in practice a range of social psychological and practical factors tend to generate a gap between the intended meaning of such narratives and their public or social meaning amongst different audiences. By illuminating the historical narrative pluralism that can arise both within and beyond the international criminal courtroom, this article calls for greater critical awareness of the constructed nature of the historical narratives rendered within international criminal judgments, as well as a sobering of the expectations that are typically placed on international criminal courts both with respect to the construction of narratives within the courtroom and their reception beyond it.
\end{abstract}

Keywords: Public international law, history, international criminal courts, justice, narratives, pluralism.

\section{INTRODUCTION}

The field of international criminal justice is situated at the confluence of multiple co-existing, competing and cross-fertilizing legal regimes. ${ }^{1}$

* Fellow, School of International Relations at Fundaçao Getulio Vargas (FGV), São Paulo, Brazil; Ph.D., International Law, Graduate Institute of International and Development Studies (summa cum laude avec les félicitations du jury); LL.M., International Law, University of Leiden (cum laude); B.A., M.A., Law, Jesus College, University of Cambridge; barrie.sander@, graduateinstitute.ch.

${ }^{1}$ E van Sliedregt and S Vasiliev, 'Pluralism: A New Framework for International Criminal Justice' in E van Sliedregt and S Vasiliev (eds), Pluralism in International Criminal Law (Oxford University Press 2014) 3, 13. 
Institutionally, the field is host to a plurality of international and domestic criminal courts, each with varied jurisdictional frameworks, rules of procedure and evidence, and contexts of operation. ${ }^{2}$ Normatively, the field is host to a plurality of actors, informed by diverse legal traditions, influenced by varied interpretative methodologies, and often in dialogue with other interrelated and overlapping domains including the fields of human rights and transitional justice. ${ }^{3}$ Factually, the field examines a plurality of mass atrocity situations, each distinct in terms of their location, participants, size and scope. ${ }^{4}$ And observationally, the field has been examined and scrutinized from a range of perspectives - spanning disciplines as diverse as law, criminology, anthropology, political science, sociology, psychology, history and philosophy - each seeking to understand particular dimensions of its origins, rationales, meanings and effects. ${ }^{5}$

In contrast to the field's pluralist nature, many of the expectations that have been placed on international criminal courts entail aspirations towards consistency and uniformity. One such expectation is the aspiration for international criminal courts to construct consistent and authoritative historical narratives about the mass atrocity situations that fall within their purview. The roots of this yearning for a consistent and coherent historical record are traceable to our human impulse to try to make sense of mass atrocities. As Mark Osiel has observed, episodes of mass violence are not the

2 See generally C Stahn and L van den Herik, “"Fragmentation", Diversification and "3D" Legal Pluralism: International Law as the Jack-in-the-Box' in L van den Herik and C Stahn (eds), The Diversification and Fragmentation of International Criminal Law (Martinus Nijhoff Publishers 2012) 21, 30ff; and van Sliedregt and Vasiliev (n 1) 20-9.

3 See generally Stahn and van den Herik (n 2) 23-6 and 43-56; van Sliedregt and Vasiliev (n 1) 29-34; D Robinson, 'The Identity Crisis of International Criminal Law' (2008) 21 LJIL 925; A Clapham, 'Concluding Remarks - Three Tribes Engage on the Future of International Criminal Law' (2011) 9 JICJ 689; and P Dixon and C Tenove, 'International Criminal Justice as a Transnational Field: Rules, Authority and Victims' (2013) 7 IJTJ 393. On the relationship between the fields of international criminal justice and human rights, see generally 'Symposium: The Influence of the European Court of Human Rights' Case Law on (International) Criminal Law' (2009) 9 JICJ 571; and 'Special Issue: The Cross-fertilisation Rhetoric in Question: Use and Abuse of the European Court's Jurisprudence by International Criminal Tribunals' (2015) 84 NordJIntlL 363. On the relationship between the fields of international criminal justice and transitional justice, see generally A Bisset, Truth Commissions and Criminal Courts (Cambridge University Press 2012).

${ }^{4}$ See generally NA Combs, 'Deconstructing the Epistemic Challenges to Mass Atrocity Prosecutions' 75 Wash\&LeeLRev (forthcoming); and A Smeulers, 'Perpetrators of International Crimes: Towards A Typology' in A Smeulers and R Haveman (eds), Supranational Criminology: Towards a Criminology of International Crimes (Intersentia 2008) 233.

5 See generally S Nouwen, 'International Criminal Law: Theory All over the Place', University of Cambridge Legal Studies Research Paper No 44/2015 (2015); S Vasiliev, 'On Trajectories and Destinations of International Criminal Scholarship', (2015) 28 LIJL 701; M Burgis-Kasthala, 'Scholarship as Dialogue? TWAIL and the Politics of Methodology' (2016) 14 JICJ 921; E van Sliedregt, 'International Criminal Law: Over-studied and Underachieving?' (2016) 19 LIJL 1; C Kreß, Towards a Truly Universal Invisible College of International Criminal Lawyers (Torkel Opsahl Academic EPublisher 2014); and R Cryer, 'The Philosophy of International Criminal Law' in A Orakhelashvili (ed), Research Handbook on the Theory and History of International Law (Edward Elgar 2011) 232. 
types of situations in respect to which 'we feel comfortable about letting a hundred interpretive flowers bloom', such events generally triggering 'the residual positivist $[\ldots]$ in virtually everyone' ${ }^{6}$

In practice, the rhetoric that has tended to accompany the operation of international criminal courts has often emphasized the importance of producing a clear and authoritative historical account. For instance, Larry Johnson, one of the drafters of the Statute of the International Criminal Tribunal for the former Yugoslavia (ICTY), has argued that one of the tribunal's major contributions has been 'to uncover the facts, find the truth, [...] and refute those who deny that such atrocities ever occurred'. ${ }^{7}$ This perspective has even been endorsed on the ICTY's official website, which lists as one of the tribunal's principal achievements 'creating a historical record, combatting denial and preventing attempts at revisionism' ${ }^{8}$ Similarly, former ICTR President Judge Pillay previously asserted that the tribunal was establishing 'a record which will help keep alive the world's collective memory' of what happened in Rwanda in 1994, ${ }^{9}$ while former ICTR President Judge Byron similarly suggested that 'among the most basic and most important of the Tribunal's achievements has been the accumulation of an indisputable historical record'. ${ }^{10}$ These sentiments only serve to heighten expectations that international criminal courts are capable of acting as mechanisms of historical closure. ${ }^{11}$

In contrast to the field's aspirations towards narrative consistency and closure, this article examines the historical narrative pluralism that can arise both within and beyond the international criminal courtroom. In particular, the article seeks to demonstrate that the historical narratives constructed within international criminal judgments are neither static nor final, but subject to a process of ongoing contestation and evolution over time. ${ }^{12}$ To this end, the article proceeds in three parts. The article begins by examining narrative

${ }^{6}$ M Osiel, Mass Atrocity, Collective Memory, and the Law (Transaction Publishers 1997) 265 and fn 76 (clarifying that by 'positivist', the author refers to 'positivistic philosophy of science, specifically to its notion that knowledge derives from empirical evidence and experience rather than exclusively from a priori categories. It holds, in short, that there exist facts independent of the observer who claims to discern them and of the cultural categories through which they are described').

7 LD Johnson, 'Ten Years Later: Reflections on the Drafting' (2004) 2 JICJ 368, 378.

${ }^{8}$ ICTY website, Achievements at $<$ http://www.icty.org/en/about/tribunal/achievements $>$.

9 'The Rule of Law and the Role of the Individual in the Pursuit of Human Rights by Judge Navanethem Pillay, President of the ICTR', Friedrich-Ebert Stiftung 2003 Human Rights Award, 20 May 2003, Berlin, Germany.

10 'Judge Denis Byron's Address to the UN General Assembly' ICTR Newsletter (October 2008) 1 .

${ }^{11}$ See, in this regard, JE Alvarez, 'Rush to Closure: Lessons of the Tadić Judgment' (1997-98) 96 MichLRev 2031, 2033 (referring to the 'model of closure' perspective of international criminal courts).

${ }^{12}$ See similarly, D Buss, 'Expert Witnesses and International War Crimes Trial: Making Sense of Large-Scale Violence in Rwanda' in D Zarkov and M Glasius (eds), Narrative of Justice In and Out of the Courtroom: Former Yugoslavia and Beyond (Springer 2014) 23, 43. 
pluralism within the courtroom (section II). Specifically, two types of narrative pluralism are identified: first, inter-court narrative pluralism, which arises when different courts examine the same mass atrocity situation from different perspectives; and second, intra-court narrative pluralism, which emerges when narratives constructed within an international criminal judgment are revisited in later cases adjudicated by the same court. The article then turns to examine narrative pluralism beyond the courtroom (section III). In particular, it is contended that even where international criminal courts manage to achieve inter-court and intra-court narrative consistency, in practice a range of social psychological and practical factors tend to generate a gap between the intended meaning of such narratives and their public or social meaning amongst different audiences. Having illuminated the narrative pluralism that can arise in particular institutional settings, the article concludes by calling for greater critical awareness of the constructed nature of the historical narratives rendered within international criminal judgments, as well as a sobering of the expectations that are typically placed on international criminal courts both with respect to the construction of narratives within the courtroom and their reception beyond it (section IV).

\section{NARRATIVE PLURALISM WITHIN THE COURTROOM}

Compared to the narratives put forward by the prosecution, defence, and, in some contexts, victim participants during international criminal trials, the historical narratives constructed within international criminal judgments have often been accompanied by an expectation of finality and closure. Michael Marrus, for example, has argued that 'while judgments of courts are fixed, [...] historiography moves' ${ }^{13}$ Similarly, the ancestral maxim, res judicata pro veritate habetur, stands for the proposition that an adjudicated matter is to be regarded as the truth. ${ }^{14}$ Indeed, international criminal courts have a number of doctrines in their armoury that can help solidify consensus and prevent further challenges to particular facts within the courtroom. For example, through the doctrine of judicial notice, the ICTR Appeals Chamber in Karemera et al. was able to establish the fact that genocide had occurred in Rwanda in 1994 as a fact of common knowledge. ${ }^{15}$

13 M Marrus, 'History and the Holocaust in the Courtroom' in F Brayard (ed), Le Génocide des Juifs entre procès et historie (CNRS 2000) 45, cited in L Douglas, 'Perpetrator Proceedings and Didactic Trials' in A Duff et al. (eds), The Trial on Trial: Volume 2: Judgment and Calling to Account (Hart Publishing 2006) 191, 198.

${ }^{14} \mathrm{C}$ Fournet, The Crime of Destruction and the Law of Genocide: Their Impact on Collective Memory (Ashgate 2007) xxxii.

15 Prosecutor v Karemera et al., Case No ICTR-98-44-AR73(C), ICTR Appeals Chamber, Decision on Prosecutor's Interlocutory Appeal of Decision on Judicial Notice (16 June 2006) at paras 33-38. The decision was criticized by scholars for its potential to undermine the fair trial rights of the accused, in particular in light of the willingness of the ICTR to infer the genocidal intent of an accused in part from proof of a nationwide genocidal campaign. See, for example, 
In practice, however, judicially constructed narratives are often less final and uniform than is generally assumed. ${ }^{16}$ Most obviously, the narratives rendered within trial judgments may be subject to alteration on appeal. Additionally, judgments may not be unanimous, dissenting opinions of individual judges constituting a further potential source of narrative pluralism. ${ }^{17}$ In the case of Šešelj, for example, the conclusion of the ICTY Trial Chamber's majority that there was no widespread or systematic attack on civilians across large areas of Bosnia-Herzegovina and Croatia was directly countered by Judge Lattanzi in dissent, who argued that 'no trier of fact could reasonably reach' such a conclusion based on the evidence. ${ }^{18}$ This section seeks to move beyond these well-documented forms of narrative pluralism to illuminate the ways in which the historical narratives constructed within international criminal judgments may be revisited and contested by other courts (intercourt narrative pluralism), as well as other cases adjudicated by the same court (intra-court narrative pluralism).

\section{A. Inter-Court Narrative Pluralism}

At the broadest level, narrative pluralism may emerge between the judgments of different courts that have been mandated to examine the same mass atrocity situation. Lawrence Douglas, for example, has argued that 'attention must be paid to ways in which specific trials revisit and revise their juridical precursors, and in so doing participate in, and contribute to, an evolving juridical understanding of traumatic history'. ${ }^{19}$

A clear illustration of inter-court narrative pluralism may be revealed by contrasting the judgment of the District Court of Jerusalem in the case of Adolf Eichmann with the judgment of the International Military Tribunal

KJ Heller, Prosecutor v Karemera, Ngirumpatse \& Nzirorera. Case No ICTR-98-44-AR73(C). Decision on Prosecutor's Interlocutory Appeal of Decision on Judicial Notice' (2007) 101 AJIL 157, 161-2; and NHB Jørgensen, 'Genocide as a Fact of Common Knowledge' (2007) 56 ICLQ 885, 895. See, however, Prosecutor v Karemera et al., Case No ICTR-98-44-AR73(C), ICTR Appeals Chamber, Decision on Motions for Reconsideration (1 December 2006) at para 16 (emphasizing that 'the taking of judicial notice of genocide does not, in itself, go to alleged conduct or acts of the Applicants as charged in the indictment').

${ }^{16}$ See similarly L Douglas, 'Perpetrator Proceedings and Didactic Trials' in A Duff et al. (eds), The Trial on Trial: Volume 2: Judgment and Calling to Account (Hart Publishing 2006) 191, 198 ("it does not follow that the picture of history presented in any specific trial is fixed by the fact that a trial court must render an unequivocal verdict').

${ }^{17}$ For analysis of judicial dissent in the international criminal context, see generally, H Mistry, 'The Paradox of Dissent: Judicial Dissent and the Projects of International Criminal Justice' (2015) 13 JICJ 449; N Jain, 'Radical Dissents in International Criminal Trials' (2017) 28(4) EJIL (2017) 1163; and G Simpson, Law, War \& Crime: War Crimes Trials and the Reinvention of International Law (Polity Press 2007) 92-101.

18 Prosecutor v Šešelj, Case No IT-03-67-PT, ICTY Trial Chamber, Judgment (31 March 2016) at paras 192-193; and Prosecutor v Šešelj, Case No IT-03-67-PT, ICTY Trial Chamber, Partially Dissenting Opinion of Judge Flavia Lattanzi (31 March 2016) at para 39.

19 Douglas (n 16) 199. 
(IMT) at Nuremberg. Although both judgments examined Nazi atrocities committed during the Second World War, the narratives constructed within them diverged in two important respects.

First, the Nuremberg and Eichmann judgments accorded differing degrees of space to the voices of the victims of Nazi atrocities. During the Nuremberg trial, US Prosecutor Robert Jackson had relied primarily on documentary evidence, a strategy driven both by fear and circumstance. ${ }^{20}$ In terms of fear, although survivor testimony may have served to humanize the narratives emanating from the IMT, ${ }^{21}$ Jackson was concerned that such evidence would lack credibility as a means for establishing a historical record and could too easily be dismissed as propaganda. ${ }^{22}$ In terms of circumstance, the Nazis' fanatical commitment to meticulous record-keeping constituted a convenient mountain of evidence for Jackson to rely on, ${ }^{23}$ there being no better material to prove the crimes of the Nazis than their own words drawn from their own archives. ${ }^{24}$ As a result, both at trial and in the judgment of the IMT, the voices of victims were largely overlooked. ${ }^{25}$ By contrast, the voices of victims were placed at the centre of the Eichmann trial. As Israeli Prosecutor Gideon Hausner explained, 'I knew we needed more than a conviction; we needed a living record of a gigantic human and national disaster.' 26 For Hausner, only victim testimony would be able to 'reach the hearts of men' and it was therefore imperative to give their voices a prominent place in the trial. ${ }^{27}$ As a result, the experiences of victims became a significant feature of not only the Prosecutor's narrative at trial but also the judgment of the District Court of Jerusalem. ${ }^{28}$

Second, the Nuremberg and Eichmann judgments constructed contrasting narratives about the Holocaust. As is well known, Article 6(c) of the

20 See NA Combs, Fact-Finding without Facts the Uncertain Evidentiary Foundations of International Criminal Convictions (Cambridge University Press 2010) 11; E Stover, The Witnesses: War Crimes and the Promise of Justice in The Hague (University of Pennsylvania Press 2005) 18; and L Douglas, The Memory of Judgment: Making Law and History in the Trials of the Holocaust (Yale University Press 2001) 16.

21 See Stover (n 20) 19 (noting that 'eyewitness and survivor testimony would humanize the plight of Nazi victims'); and Douglas (n 20) 17-18 (noting that William J Donovan, Jackson's first deputy, argued in favour of building the case of the prosecution around eyewitness testimony so as to give the trial 'an affirmative human aspect').

22 RH Jackson, The Nürnberg Case (Alfred A Knopf 1947) 10.

23 See, for example, A Tusa and J Tusa, The Nuremberg Trial (1983) 100-1, cited in Combs (n 20) 11 (noting that the Nazis 'had a mania for writing things down. It is an amazing psychological phenomenon that not one of these men could have a minor political conversation without recording it.').

24 See, for example, S Landsman, 'The Eichmann Case and the Invention of the Witness-Driven Atrocity Trial' (2012) 51 ColumJTransnatlL 69, 73.

25 See, for example, ibid 77; L Moffett, 'The Role of Victims in the International Criminal Tribunals of the Second World War' (2012) 12 IntCLR 245, 249; and Stover (n 20) 18.

26 G Hausner, Justice in Jerusalem (Harper \& Row 1966) 291-2.

28 See, for example, The Attorney General of the Government of Israel v Eichmann, Criminal Case No 40/61, District Court of Jerusalem, Judgment (11 December 1961) at paras 129-130 (recounting evidence of survivors concerning living conditions in the Nazi camps and ghettos). 
Nuremberg Charter provided that for the enumerated prohibited acts to constitute crimes against humanity, they must have been committed 'in execution of or in connection with any crime within the jurisdiction of the Tribunal' ${ }^{29}$ In practice, this war nexus requirement seemed to motivate the IMT to conflate crimes against humanity with war crimes when entering convictions against defendants. ${ }^{30}$ Indeed, only two defendants-Julius Streicher and Baldur von Schirach-were convicted of crimes against humanity independently of war crimes. ${ }^{31}$ The result of this framing was to focus the historical narratives constructed within the judgment on the Nazi war effort. As historian Michael Marrus has argued, war was considered to be at the heart of Nazi criminality in the Nuremberg proceedings: ${ }^{32}$

[E]verything else the Nazis did, including their anti-Jewish campaign, tended to be seen in instrumental terms - as a means to hold the Nazi movement together, eliminate enemies, consolidate power, mobilize support, or carry out robbery or intimidation.

By placing such an emphasis on the war, the significance of racially-motivated persecutions conducted largely independent of the war effort was diminished; the result was an interpretation of the Nazi regime that was, as Martti Koskenniemi has put it, 'predominantly one of aggressive militarists that put its racist and genocidal character in a secondary and at times almost invisible role'. 33

29 There was initially a discrepancy between the English, French and Russian versions of the Nuremberg Charter which raised doubts as to whether all types of crimes against humanity had to be tied to crimes against peace or war crimes, or simply the sub-category of persecution-like crimes against humanity. On the famous Semicolon Protocol of 6 October 1945, which has generally been considered to have clarified that all crimes against humanity must be linked to crimes against peace or war crimes, see Douglas (n 20) 53-4.

${ }^{30}$ Göring and others, Nuremberg International Military Tribunal, Judgment (1 October 1946) Trial of the Major War Criminals before the International Military Tribunal, Nuremberg, 14 November 1945-1 October 1946: Volume I (Nuremberg IMT, 1947) 171, at 254-255 ('[F]rom the beginning of the war in 1939 War Crimes were committed on a vast scale, which were also Crimes against Humanity; and insofar as the inhumane acts charged in the Indictment, and committed after the beginning of the war, did not constitute War Crimes, they were all committed in execution of, or in connection with the aggressive war, and therefore constituted Crimes against Humanity.'). See, in this regard, R Clark, 'Crimes Against Humanity at Nuremberg' in G Ginsburgs and VN Kudriavtsev (eds), The Nuremberg Trial and International Law (Martinus Nijhoff Publishers 1990) 177, 194 ('The discussion of the two offenses is indeed quite jumbled up').

31 For further discussion of the different framing of these convictions within the different language versions of the IMT judgment, see generally G Acquaviva, 'At the Origins of Crimes Against Humanity: Clues to a Proper Understanding of the Nullum Crimen Principle in the Nuremberg Judgment' (2011) 9 JICJ 881; and KS Gallant, The Principle of Legality in International and Comparative Criminal Law (Cambridge University Press 2009) 119-24.

32 MR Marrus, 'History and the Holocaust in the Courtroom' in R Smelser (ed), Lessons and Legacies V: The Holocaust and Justice (Northwestern University Press 2002) 215, 218. See similarly Simpson (n 17) 91 ('a large-scale conspiracy to commit an aggressive war became the primary motif of the trial').

${ }^{33}$ M Koskenniemi, 'From Impunity to Show Trials' (2002) 6 MaxPlanckYrbkUNL 1, 20. 
By contrast, relying on the Nazis and Nazi Collaborators (Punishment) Law pursuant to which Adolf Eichmann had been charged, the District Court of Jerusalem was able to render a narrative that placed the Holocaust front and centre of its judgment, taking care to distinguish between crimes against the Jewish people and crimes against humanity. ${ }^{34}$ According to the District Court, Nazi policy had evolved over time, with the beginning of the war against the Soviet Union in June 1941 marking a shift in policy towards 'the third and final stage in the persecution of the Jews within the area of German influence, namely the stage of total extermination'. ${ }^{35}$ Reflecting on the acts in which Eichmann had been involved, the Court drew a distinction between acts of persecution committed prior to August 1941 which had not been linked to a policy of physical extermination and were therefore characterized as crimes against humanity, and acts committed after August 1941 which were linked to such a policy and were therefore characterized as crimes against the Jewish people. ${ }^{36}$

The judgments of the IMT and District Court of Jerusalem offer a clear illustration of how judicially constructed narratives can evolve over time, varying according to the jurisdictional and evidentiary choices and limitations in particular institutional contexts. Taken together, the judgments reflect what Shoshana Felman has termed the 'cross-legal nature' of certain trials, understood as 'a trial's reference to another trial, of which it recapitulates the memory, the themes, the legal questions of the arguments, and whose legal structure it repeats or reenacts - unwittingly or by deliberate design'. ${ }^{37}$ From this perspective, the Eichmann judgment may be understood as 'the deliberate historical reopening' of the Nuremberg judgment, ${ }^{38}$ ultimately leading to the production of narrative pluralism and distinct perspectives concerning the atrocities perpetrated by the Nazi regime during the Second World War.

\section{B. Intra-Court Narrative Pluralism}

Beyond inter-court narrative pluralism, it is also possible for historical narratives concerning the same events to deviate within different cases adjudicated by the same international criminal court. Since episodes of mass atrocity often take place over longer periods of time and span across broader areas of territory than domestic crimes, international criminal courts have sometimes been mandated to render a collection of judgments concerning a

34 See generally WA Schabas, 'The Contribution of the Eichmann Trial to International Law' (2013) 26 LIJL 667, 670-6.

36 See, in particular, Eichmann (n 28) at paras 182-199.

37 S Felman, The Juridical Unconscious: Trials and Traumas in the Twentieth Century (Harvard University Press 2002) 61. 
particular conflict situation. ${ }^{39}$ In such circumstances, although it is possible that an overarching narrative will emerge within the various judgments rendered by the court, it is also likely that a plurality of contrasting interpretations will arise with respect to at least some of the events examined. As Lawrence Douglas has explained, '[a]s [the] prosecutorial programme unfolds-as prosecutors, judges, and other legal actors master the learning curve of complex crimesatrocity trials typically come to frame a richer, more nuanced treatment of the larger historical complex'. ${ }^{40}$ Against this background, this section identifies examples of intra-court narrative pluralism that have arisen as a result of the evidentiary, charging and legal practices of the different actors that participate within international criminal proceedings.

\section{Evidence-driven narrative pluralism}

The historical narratives constructed within international criminal judgments have sometimes evolved over time as a result of discrepancies concerning the evidence that has been put before them and the scrutiny to which it has been subjected in different cases. This may be illustrated by examining the evolution of the ICTR's findings concerning whether the Rwandan genocide had been planned in advance by Hutu extremists prior to its commencement in April 1994. ${ }^{41}$

In its early judgments, several ICTR Trial Chambers concluded in fairly unambiguous terms that the Rwandan genocide had been planned in advance. For instance, in its judgment in the case of Akayesu, the Trial Chamber concluded that the genocide 'appears to have been meticulously organized', upholding the view of expert witness Alison Des Forges who had referred to 'centrally organized and supervised massacres'. ${ }^{42}$ To reach this conclusion, the Trial Chamber relied on a range of evidence, including 'the existence of lists of Tutsi to be eliminated', 'the arms caches in Kigali which Major-General Dallaire mentioned and regarding whose destruction he had sought the UN's authorization in vain', 'the training of militiamen by the Rwandan Armed Forces', as well as 'the psychological preparation of the

39 R Steinke, The Politics of International Criminal Justice: German Perspectives from Nuremberg to The Hague (Hart Publishing 2012) 13.

${ }^{40}$ L Douglas, 'Truth and Justice in Atrocity Trials' in WA Schabas (ed), The Cambridge Companion to International Criminal Law (Cambridge University Press 2016) 34, 46.

${ }^{4}$ For further discussions pertaining to this issue, see generally K Bachmann and A Fatić, The UN International Criminal Tribunals: Transition without Justice? (Routledge 2015) 247-51; and Buss (n 12).

42 Prosecutor v Jean-Paul Akayesu, Case No ICTR-96-4-T, ICTR Trial Chamber, Judgment (2 September 1998) at para 126. See similarly, Prosecutor v Clément Kayishema and Obed Ruzindana, Case No ICTR-95-1-T, ICTR Trial Chamber, Judgement (21 May 1999) at para 289; and Prosecutor v Nahimana et al., Case No ICTR-99-52-T, ICTR Trial Chamber, Judgement and Sentence (3 December 2003) at para 118. For further information on the views of expert witness Alison Des Forges concerning the planned nature of the Rwandan genocide, see generally Human Rights Watch, The Rwandan Genocide: How It Was Prepared (April 2006). 
population to attack the Tutsi' ${ }^{43}$ In Kayishema, the Trial Chamber was even more explicit, expressly concluding that 'there indeed was a genocidal plan in place prior to the downing of the President's airplane in April 1994' ${ }^{44}$

Despite the confident tone of these early pronouncements, later judgments of the Trial Chamber cast doubt on these findings, subjecting the planned nature of the genocide to increasing amounts of scrutiny. In Bagosora et al., for example, the ICTR Prosecutor alleged that four military leaders had conspired to commit genocide prior to its commencement. At trial, the Prosecutor argued that the evidence revealed a growing and developing preparedness on the part of the accused to commit genocide from late 1990, which later crystallized into a conspiracy to commit genocide several months or possibly even a year prior to its commencement in April 1994. ${ }^{45}$ The Prosecution's case relied on statements made by the accused, their affiliation with clandestine organizations, as well as their role in the preparation of lists and military training of civilians. ${ }^{46}$

In its judgment, the ICTR Trial Chamber accepted that it 'cannot exclude that there were in fact plans prior to 6 April to commit genocide in Rwanda' ${ }^{47}$ In particular, there were 'certain indications' in the evidence of a prior plan or conspiracy to perpetrate genocide, including a campaign to covertly arm and train civilian militiamen, efforts to put in place a 'civil defence' system made up of 'resistance' groups, and the creation of lists primarily aimed at identifying suspected accomplices of the RPF and opponents to the Habyarimana regime. ${ }^{48}$ Yet, whilst acknowledging that these preparations were 'completely consistent with a plan to commit genocide', the Trial Chamber added that they were also 'consistent with preparations for a political or military power struggle' ${ }^{49}$ Importantly, the Prosecution's case on this charge had been primarily circumstantial so the Trial Chamber could only convict the accused if conspiracy to commit genocide was the only reasonable inference that could be drawn from the evidence. ${ }^{50}$ Since the evidence suggested more than one reasonable inference, the Trial Chamber concluded that the Prosecution had failed to prove beyond reasonable doubt that the four accused had conspired to commit genocide prior to its commencement on 7 April 1994. ${ }^{51}$

${ }^{43}$ Akayesu (n 42), at para 126.

${ }^{44}$ Kayishema and Ruzindana (n 42) at para 528.

45 Prosecutorv Bagosora et al., Case No ICTR-98-41-T, ICTR Trial Chamber, Judgement and Sentence (18 December 2008) at para 2094. For a useful account of the prosecution's narrative in its indictment, see Bachmann and Fatić (n 41) 249-50. $\quad{ }^{46}$ Bagosora et al. (n 45) at para 2097.

${ }^{47}$ Bagosora et al. (n 45) at para 2107 (emphasis added). See similarly Prosecutor $v$ Ndindilyimana et al., Case No ICTR-00-56, ICTR Trial Chamber, Judgement and Sentence (17 May 2011) at para 2066 ('the Chamber cannot rule out the possibility of the existence of plans to commit genocide'). $\quad 48$ Bagosora et al. (n 45) at paras 2107-2109.

49 Bagosora et al. (n 45) at para 2110. See similarly Ndindilyimana et al. (n 47) at para 2068 ('while certain elements proved by the Prosecution could collectively be suggestive of a conspiracy to commit genocide, they are also consistent with [...] a political and military power struggle against the RPF').

${ }^{50}$ Bagosora et al. (n 45) at para 2110.

${ }_{51}$ Bagosora et al. (n 45) at para 2113. The ICTR has acquitted other individuals of conspiracy to commit genocide before its commencement. See, for example, Prosecutor v Juvénal Kajelijeli, Case 
This aspect of the case is significant not only for its legal verdict, but also for the Trial Chamber's attempt to limit the historical significance of its findings. The Chamber emphasized that the question under examination was not the broader issue of 'whether there was a plan or conspiracy to commit genocide in Rwanda', but rather a more limited inquiry into whether the Prosecution had proven beyond reasonable doubt that the four accused had conspired amongst themselves or with others to commit genocide before it unfolded on 7 April 1994. ${ }^{52}$ Moreover, the Chamber explained how its task had been restricted by 'exacting standards of proof and procedure, the specific evidence on the record before it and its primary focus on the actions of the four accused in this trial'. ${ }^{53}$ As such, although 'a firm foundation' for the crime of conspiracy to commit genocide could not be constructed from the 'fractured bricks' of evidence that had been put before the tribunal in this case, it remained conceivable that 'newly discovered information, subsequent trials or history' might demonstrate a conspiracy involving the accused to commit genocide, ${ }^{54}$ and it was also possible that 'some [other] military or civilian authorities did intend these preparations as part of a plan to commit genocide'. 55

What emerges from the case of Bagosora et al., therefore is a notable reticence on the part of the Trial Chamber-in marked contrast to the tribunal's earlier judgments - to provide historical narrative closure on the issue of whether the genocide was planned in advanced. As Doris Buss has observed, the judgment in Bagosora et al. 'reveals a court that was both more knowledgeable about Rwanda while less confident in its ability to know the causes and contexts of the 1994 genocide'. ${ }^{56}$

The evidence-driven narrative pluralism that emerged at the ICTR is far from an isolated example. At the ICTY, for instance, judges in the cases of Tadić and Perisić reached divergent factual findings concerning the relationship between the Bosnian Serb Army (the VRS) and the Yugoslav Army (the VJ). ${ }^{57}$ In Tadić, the Appeals Chamber found, in the context of determining the classification of the armed conflict, that 'the VRS and the VJ did not, after May 1992, comprise two separate armies in any genuine sense', but rather 'the renamed Bosnian Serb army still comprised one army under the command of the General Staff of the VJ

No ICTR-98-44A-T, ICTR Trial Chamber, Judgement and Sentence (1 December 2003) at paras 449 and 794-796; Ndindilyimana et al. (n 47) at para 2069; and Prosecutor v Édouard Karemera and Mathieu Ngirumpatse, Case No ICTR-98-44-A, ICTR Appeals Chamber, Judgment (29 September 2014) at paras 731-742. $\quad{ }_{52}$ Bagosora et al. (n 45) at para 2092.

53 Bagosora et al. (n 45) at para 2112. See similarly F Gaynor, 'Uneasy Partners - Evidence, Truth and History in International Trials' (2012) 10 JICJ 1257, 1272 (observing how 'a conscientious historian, analysing the same evidence, might well conclude that it was more probable than not that there had been a high-level conspiracy to commit genocide in Rwanda before it unfolded'). $\quad{ }^{54}$ Bagosora et al. (n 45) at para 2112.

56 Buss (n 12) 24.

57 See generally MJ Ventura, 'Specific direction à la Perišić, the Taylor Appeal Judgment and what it could mean for the ICTY Appeals Chamber in Šainović et al. - Part I' Spreading the Jam (8 January 2014). 
in Belgrade' ${ }^{58}$ By contrast, in Perisić, the Appeals Chamber concluded, in the context of determining whether the requirements for aiding and abetting had been satisfied, that 'the VRS and the VJ [were] separate and independent military entities'. ${ }^{59}$

Similarly, in the cases of Milutinović et al. and Đorđević, two Trial Chambers at the ICTY reached divergent conclusions regarding a joint criminal enterprise (JCE) that had been orchestrated by the Serbian leadership in Kosovo. ${ }^{60}$ In each case, the Trial Chambers identified the existence of a JCE in extremely similar terms. In Milutinović et al., the Trial Chamber identified a JCE whose common purpose was 'to ensure continued control by the FRY and Serbian authorities over Kosovo' by forcibly displacing the Kosovo Albanian population both within and outside Kosovo through 'a widespread and systematic campaign of terror and violence'. ${ }^{61}$ Since the JCE members were aware that it would be unrealistic to displace all Kosovo Albanians from Kosovo, the common purpose was 'to displace a number of them sufficient to tip the demographic balance more toward ethnic equality and in order to cow the Kosovo Albanians into submission'. ${ }^{62}$ In Đorđević, the Trial Chamber identified a common plan 'to modify the ethnic balance in Kosovo by waging a campaign of terror against the Kosovo Albanian civilian population, a plan which included murders, deportations, forcible transfers and the destruction of religious and culturally significant property' ${ }^{63}$

Despite their similarity, the Trial Chambers reached varying conclusions regarding the membership of the JCEs. Whereas the Trial Chamber in Milutinović et al. concluded that Ojdanić and Lazarević, who were defendants in that case, were not members of the JCE, ${ }^{64}$ the Trial Chamber in Đorđević expressly included Ojdanić and Lazarević within its list of JCE members. ${ }^{65}$ On appeal in the case of Đorđević, the defendant questioned the

${ }^{58}$ Prosecutor v Duško Tadić, Case No IT-94-1-A, ICTY Appeals Chamber, Judgment, (15 July 1999) paras 151-152.

59 Prosecutor v Momčilo Perišić, Case No IT-04-81-A, ICTY Appeals Chamber, Judgment (28 February 2013) at para. 46.

${ }^{60}$ For a similar example in the jurisprudence of the ICTR, see MA Drumbl, 'The Curious Criminality of Mass Atrocity: Diverse Actors, Multiple Truths, and Plural Responses' in van Sliedregt and Vasiliev (n 1) 68, 97-9 (discussing divergent findings in the ICTR cases related to the Nyange parish church massacre).

${ }^{61}$ Prosecutor v Milutinović et al., Case No IT-05-87-T, ICTY Trial Chamber, Judgement: Volume 3 of 4 (26 February 2009) at para 95.

${ }_{62}$ Milutinović et al. (n 61) at para 95. The Trial Chamber's analysis and findings as regards the common purpose of the JCE were upheld on appeal. Prosecutor $v$ Šainović et al., Case No IT-05-87A, ICTY Appeals Chamber, Judgement (23 January 2014) at paras 604 and 664.

${ }_{63}$ Prosecutor v Vlastimir Dordević, Case No IT-05-87/1-T, ICTY Trial Chamber, Public Judgement with Confidential Annex: Volume I of II, 23 February 2011, at para 2126. The Trial Chamber's analysis and findings as regards the common purpose of the JCE were upheld on appeal. See Prosecutor v Vlastimir Dorđević, Case No IT-05-87/1-A, ICTY Appeals Chamber, Judgement (27 January 2014) at paras 139-141 and 158.

${ }_{64}$ Milutinović et al. (n 61) at paras 618 (regarding Ojdanić) and 919 (regarding Lazarević).

${ }^{65}$ Dordević Trial Judgment (n 63) at paras 2127 and 2211. 
discrepancy between the two cases, contending that 'no reasonable trial chamber could have concluded that Ojdanić and Lazarević were members of the JCE', especially bearing in mind that there was 'no more evidence before the Trial Chamber in Đorđević's trial than was before the Trial Chamber in Milutinović et al.' 66

In response, the Appeals Chamber dismissed the defendant's argument by explaining its general position that 'findings of criminal responsibility made in a case before the Tribunal are binding only for the individual accused in that specific case'. ${ }^{67}$ With this in mind, the Appeals Chamber elaborated as follows: 68

[Whereas] in the Milutinović et al. case the Trial Chamber was required to scrutinise the actus reus and mens rea of each JCE member who was accused in that case in order to reach a conclusion beyond a reasonable doubt on their individual criminal responsibility [...], in the present case, findings concerning those individuals are only relevant to the analysis aimed at establishing that Đorđević acted in concert with a plurality of persons and shared the common purpose to further the JCE, in order to make a finding beyond a reasonable doubt regarding his individual criminal responsibility only.

In addition, the Appeals Chamber noted that, in making factual findings, judges rely 'solely and exclusively on the evidence adduced in the particular case' and, as such, 'it is entirely acceptable that on the basis of two different case records, judges arrive at different conclusions, even if they concern the same events'. ${ }^{69}$ In this way, the Appeals Chamber confirmed that not only was evidence-driven narrative pluralism between different cases concerning similar events possible, it was also justifiable.

\section{Charge-driven narrative pluralism}

Beyond evidence-driven narrative pluralism, divergent narratives may also arise within the judgments of different cases as a result of prosecutorial decisions concerning the scope and content of charges, as well as judicial decisions concerning their oversight of indictments.

Turning first to prosecutorial discretion, international prosecutors are under no obligation to charge different defendants consistently with respect to the same factual incidents in different cases. As Mark Osiel has observed, 'the same period of events, people, and facts [can be] grouped differently (i.e., into differently defined enterprises) from one indictment to the next', subject only to the limits of what the evidence permits. ${ }^{70}$ As such, where defendants are tried separately in relation to the same factual incidents, the potential always exists for inconsistencies to arise in prosecutorial charging practices.

\footnotetext{
${ }^{66}$ Dorđević Appeals Judgment (n 63) at para 135. $\quad 67$ ibid, para 142. $\quad 68$ ibid.

69 ibid, para 143.

70 M Osiel, Making Sense of Mass Atrocity (Cambridge University Press 2009) 75.
} 
A range of factors might account for such inconsistencies, including new evidence coming to light in the preparation of cases brought at a later period in time, as well as incentives to bring a narrower range of charges in particular cases as a result of completion strategies. ${ }^{71}$ Where cases concern the same factual incidents, differences in prosecutorial charging practices can lead to narrative pluralism concerning those incidents. The potential for charge-driven narrative pluralism may be illustrated by contrasting the ICTY Prosecutor's charging strategy with respect to genocide allegations in Bosnia in the case of Slobodan Milošević on the one hand and the case of Jovica Stanišić and Franko Simatović on the other. ${ }^{72}$

In Milošević, ICTY Prosecutor Carla Del Ponte applied for the joinder of three indictments that had been issued against the defendant concerning alleged serious violations of international humanitarian law in Kosovo, Croatia, and Bosnia and Herzegovina. ${ }^{73}$ Del Ponte argued that Milošević had been involved in a single 'transaction' or common scheme to create a 'Greater Serbia' that warranted the joinder of the three indictments. ${ }^{74}$ Although the Trial Chamber initially only permitted the joinder of the Croatia and Bosnia and Herzegovina indictments, ${ }^{75}$ the Prosecutor's argument was successful on appeal and all three indictments were eventually joined together to form a single trial. ${ }^{76}$ The indictment therefore promised to paint a picture of how Belgrade - not only Milošević but also several other individuals and institutions of the Serbian administration - was implicated in a criminal scheme whose scope spanned from Croatia, through Bosnia, to Kosovo.

For present purposes, of prime interest are the charges of genocide brought against Milošević in the Bosnia Indictment. By the time of the Trial Chamber's Rule 98bis decision, the genocide charges against Milošević concerned the Bosnian territories of Brčko, Prijedor, Sanski Most, Srebrenica, Bijeljina, Kotor Varos, Kljuc, and Bosanski Novi. ${ }^{77}$ The ICTY Prosecutor submitted

${ }^{71}$ See, in this regard, S Ford, 'The Complexity of International Criminal Trials Is Necessary' (2015) 48 GeoWashIntlLRev 151, 193-4 (arguing, based on an empirical study, that adopting a symbolic charging strategy would have reduced trial complexity of the ten most complex cases at the ICTY by around 27 per cent).

${ }_{72}$ This example was brought to my attention by F Hartmann, 'Abdicated Legacy: The Prosecution's Use of Evidence from Milošević' in T Waters (ed), The Milošević Trial: An Autopsy (Oxford University Press 2014) 465.

73 See Prosecutor v Slobodan Milošević, Case Nos IT-99-37-AR73, IT-01-50-AR73 and IT-0151-AR73, ICTY, Appeals Chamber, Decision on Prosecution's Interlocutory Appeal from Refusal to Order Joinder (1 February 2002).

${ }^{74}$ Prosecutor v Slobodan Milošević, Case Nos IT-99-37-PT, IT-01-50-PT and IT-01-51-PT, ICTY, Trial Chamber, Decision on Prosecution's Motion for Joinder (13 December 2001) at paras 16 and 42. Rule 49 of the ICTY Rules of Procedure and Evidence provides that '[t]wo or more crimes may be joined in one indictment if the series of acts committed together form the same transaction, and the said transaction, and the said crimes were committed by the same accused'.

${ }_{75}$ Milošević (n 74) at paras 52-53.

${ }_{76}$ Milošević (n 73).

77 Prosecutor v Slobodan Milošević, Case No IT-02-54-T, ICTY Trial Chamber, Decision on Motion for Judgement of Acquittal (16 June 2004) at para 138. 
that the defendant had participated in a JCE, whose common objective consisted of 'the destruction of the Bosnian Muslim group in that part of the territory of Bosnia and Herzegovina intended to be included in the Serbian state'. ${ }^{78}$ This JCE begged the question as to how precisely Milošević was linked to the Bosnian Serb leadership. The missing link between Belgrade and the crimes committed by Serb paramilitaries in Bosnia was the Serb Security Service operated by Stanišić and Simatović. ${ }^{79}$ In other words, Stanišić and Simatović were alleged to have been 'the essential go-betweens' connecting Milošević with the Bosnian Serb leadership, "not only indispensable to the factual projection of Milošević's power but also an irreducible link in the legal argument' 80

In light of Milošević's death prior to judgment, the ICTY was unable to render a final verdict concerning Milošević's precise role and guilt with respect to the Bosnian genocide charges. In its Rule 98bis decision, which concerned a motion for acquittal that had been requested by the defendant's amici curiae and relied upon an extremely low standard of review, ${ }^{81}$ the Trial Chamber preserved all counts against Milošević, although Judge Kwon dissented on the charge of genocide pursuant to the basic form of JCE, concluding that he could not agree with the majority that 'there is sufficient evidence upon which a Trial Chamber could find beyond reasonable doubt that the Accused had the dolus specialis required for genocide'; ${ }^{2}$ by contrast, Judge Kwon agreed with the majority with respect to the other theories of liability that had been alleged by the prosecution, including genocide pursuant to the extended form of JCE. ${ }^{83}$ Nonetheless, neither the trial nor the Rule 98bis decision provided any clear answers concerning Milošević's links to the Bosnian Serb leadership or whether the genocide charges would have been upheld at judgment.

Given the alleged importance of the role played by Stanišić and Simatović as a conduit between Milošević and the Bosnian Serb leadership with respect to genocide, one might have expected the case against Stanišić and Simatović to have provided further clarity on this relationship. After all, as Florence Hartmann has argued, '[i]f Milošević was able to foresee the risk of

78 ibid, para 140.

79 Bachmann and Fatić (n 41) 223. See similarly, Hartmann (n 72 ) 472 (claiming that a significant part of the Prosecutor's strategy to prove that Milošević had participated in the JCE entailed demonstrating how Stanišić and Simatović had served as 'channels of communication between and among the core members of the JCE in Belgrade, and had controlled and directed Serbia's covert special forces in some of the most brutal campaigns against non-Serb civilians').

${ }^{80} \mathrm{H}$ van der Wilt, 'The Spider and the System' in Waters (n 72) 484, 487.

81 For a detailed summary of the standard of review applied in Rule 98bis decisions, see Milošević (n 77) at para 13 ('Where there is some evidence, but it is such that, taken at its highest, a Trial Chamber could not convict on it, the Motion [to acquit the defendant on those charges] is to be allowed') (emphasis added).

${ }^{82}$ Prosecutor v Slobodan Milošević, Case No IT-02-54-T, ICTY Trial Chamber, Decision on Motion for Judgement of Acquittal, Dissenting Opinion of Judge Kwon (16 June 2004) at para 1.

83 ibid, para 2. 
genocide, as the charges against him implied, logically so did Stanišić and Simatović, who were informing him of everything that occurred in the field' ${ }^{84}$ In practice, however, no genocide charges were brought by the ICTY Prosecutor against the defendants in Stanišić and Simatović. As such, the Prosecutor's narrative differed substantially compared to Milošević, 'now treating the Srebrenica genocide as a parallel criminal plan developed separately from the overarching Milošević JCE and with a separate and specific intent - in this case, a genocidal one - not shared by Stanišić and Simatović'. ${ }^{85}$

The precise rationale behind the ICTY Prosecutor's altered narrative of Serbian involvement in the Srebrenica genocide is unclear. According to Hartmann, the change in strategy may have reflected a desire not to conflict with the narrative rendered by the International Court of Justice in the Bosnian Genocide case, as well as an attempt to simplify its case against Karadžić by avoiding any suggestion that Karadžić's authority was sometimes eclipsed by Belgrade. ${ }^{86}$ It is also possible that the ICTY Prosecutor determined that there was insufficient evidence to convincingly advance the genocide charges against Stanišić and Simatović. In this regard, it is notable that the Trial Chamber's judgment in Stanišić and Simatović ultimately rejected allegations that the defendants had provided 'channels of communication' between, inter alia, Belgrade and the Bosnian Serb leadership. ${ }^{87}$

Regardless of its precise rationale, the variation in the ICTY Prosecutor's charging strategy illustrates the potential for inconsistencies to arise concerning how JCEs concerning the same events are understood at the ad hoc tribunals. In the present example, narrative pluralism did not fully emerge since Milošević's death meant that no judgment was ultimately rendered concerning the genocide allegations. Nonetheless, the Prosecutor's decision not to charge Stanišić and Simatović with genocide at the very least casts doubt on its earlier genocide allegations against Milošević, providing a further illustration of how a narrative can twist and turn during the course of a tribunal's lifetime. ${ }^{88}$

Beyond prosecutorial discretion concerning the scope and content of charges, narrative pluralism may also emerge as a result of the exercise of judicial oversight powers concerning alleged defects in the form of indictments, as

${ }^{84}$ Hartmann (n 72) $472 . \quad \quad 85$ ibid 474 (emphasis added). $\quad{ }^{86}$ ibid 479-81.

87 Prosecutor v Jovica Stanišić and Franko Simatović, Case No IT-03-69-T, ICTY Trial Chamber, Judgement (30 May 2013) at paras 2290-2304. The judgment of the Trial Chamber has recently been quashed by the Appeals Chamber, which has ordered a retrial of the defendants. See generally, Prosecutor v Jovica Stanišić and Franko Simatović, Case No IT-0369-A, ICTY Appeals Chamber, Judgement (9 December 2015).

${ }^{88}$ See, in this regard, van der Wilt (n 80) 488 (observing that 'the major blow to the structural cohesion of the JCE [originally alleged in Milošević] has been administered by the Prosecution itself, which, by eliding the indispensable links between Milošević and the acts of genocide, has caused the whole JCE to fall apart'.). 
well as requests to amend or add charges to indictments. ${ }^{89}$ These powers are significant since their exercise can potentially lead to the dismissal or omission of charges from indictments in order to safeguard the fair trial rights of the accused.

With respect to defects in the form of indictments, for example, the jurisprudence of the ad hoc tribunals has clarified that '[a]n indictment which fails to duly set forth the specific material facts underpinning the charges against the accused is defective'. ${ }^{90}$ In some instances, a vague or imprecise indictment may be cured of its defects if the Prosecutor has provided the accused with 'timely, clear and consistent information detailing the factual basis underpinning the charges against him'. ${ }^{91}$ However, where a failure to provide the accused with sufficient notice of the legal and factual reasons for the charges was found to have violated the individual's right to a fair trial, no conviction could result. ${ }^{92}$ As these tests indicate, whether an indictment was defective depended on both the actions taken by the prosecution to ensure that the fair trial rights of the accused were not prejudiced, as well as the predilections of the judges in determining whether the relevant tests had been satisfied on the facts of particular cases.

The narrative pluralism that may result from the decisions of prosecutors and judges concerning defects in the form of indictments may be illustrated by comparing how allegations of sexual violence directed against men and boys were received in the cases of Taylor and Sesay et al. at the Special Court for Sierra Leone (SCSL). In Taylor, the indictment failed to provide the accused with any notice that he was charged with any form of sexual violence other than rape, abduction or sexual slavery of women and girls. ${ }^{93}$ Nonetheless, the SCSL Prosecutor pleaded for the Trial Chamber to consider evidence of sexual violence against male victims. In response, the Trial Chamber found that neither had the Prosecutor been able to point to any references in the charging documents capable of providing timely, clear and consistent notice to the accused of such allegations, nor were the service of witness statements sufficient for this purpose. ${ }^{94}$ As such, the Trial Chamber declined to consider evidence of sexual violence against male victims in its judgment. ${ }^{95} \mathrm{By}$ contrast, in Sesay et al., although the indictment was similarly restricted to sexual violence against women and girls, the Trial Chamber found that the

89 See generally, H Friman et al., 'Charges' in G Sluiter et al. (eds) International Criminal Procedure: Principles and Rules (Oxford University Press 2013) 381, 415-22; and J Locke, 'Indictments' in L Reydams et al. (eds), International Prosecutors (Oxford University Press 2012) 604, 642-5.

${ }^{90}$ Nahimana et al. $v$ Prosecutor, Case No ICTR-99-52-A, ICTR Appeals Chamber, Judgment (28 November 2007) at para 322. See similarly Prosecutor v Kvočka et al., Case No IT-98-30/1-A, ICTY Appeals Chamber, Judgement (28 February 2005) at para 33; and Prosecutor v Moinina Fofana and Allieu Kondewa, Case No SCSL-04-14-A, SCSL Appeals Chamber, Judgment (28 May 2008) at para 443. 91 Nahimana et al. (n 90) at para 325.92 ibid, para 326.

93 Prosecutor $v$ Charles Ghankay Taylor, Case No SCSL-03-01-T, SCSL Trial Chamber, Judgment (18 May 2012) at para 124. $\quad 9_{94}$ ibid, paras 129-131. 95 ibid, para 134. 
Prosecution's disclosure - prior to the start of the Prosecution's case- of a number of witness statements, in which allegation of sexual violence against male victims had been raised, constituted adequate notice of such allegations, thereby curing the defect in the indictment. ${ }^{96}$ This finding enabled the Trial Chamber to document a number of instances of sexual violence directed against male victims in its judgment. ${ }^{97}$

\section{Law-driven narrative pluralism}

A final avenue by which narrative pluralism may emerge between different international criminal judgments is through the adoption of divergent interpretations of substantive legal categories. A clear illustration of this form of narrative pluralism occurred at the ICTR with respect to the war crimes nexus requirement.

Beyond identifying the existence of an armed conflict, a successful war crimes prosecution requires the establishment of a nexus between the conduct of the accused and the armed conflict in question. ${ }^{98}$ The nexus requirement serves the dual function of distinguishing war crimes from other international crimes on the one hand, and from ordinary domestic crimes with no association to the armed conflict on the other. ${ }^{99}$

Early in its case law, the ICTR had little difficulty identifying the existence of a non-international armed conflict between the Hutu-controlled Rwandan Armed Forces (RAF) and the Tutsi-controlled Rwandan Patriotic Front (RPF) for at least the duration of the genocide that occurred in Rwanda in $1994 .{ }^{100}$ Far more challenging was the task of establishing a nexus between the alleged crimes of the defendants on trial and the armed conflict. The central issue confronted by the tribunal in this regard was whether crimes committed

96 Prosecutor $v$ Sesay et al., Case No SCSL-04-15-T, SCSL Trial Chamber, Judgement (2 March 2009) at paras 1302-1309.

97 See, in this regard, V Oosterveld, 'Evaluating the Special Court for Sierra Leone's Gender Jurisprudence' in CC Jalloh (ed), The Sierra Leone Special Court and Its Legacy: The Impact for Africa and International Criminal Law (Cambridge University Press 2014) 234, 256-7.

98 For detailed discussions of the 'nexus' requirement, see generally K Ambos, Treatise on International Criminal Law: Volume II: The Crimes and Sentencing (Oxford University Press 2014) 140-4; R Cryer et al., An Introduction to International Criminal Law and Procedure (3rd edn, Cambridge University Press 2014) 281-2; A Cassese et al., Cassese's International Criminal Law (3rd edn, Oxford University Press 2013) 77-9; and G Mettraux, International Crimes and the Ad Hoc Tribunals (Oxford University Press 2006) 38-47.

99 Ambos (n 98) 140-1.

100 See, for example, Akayesu (n 42) at paras 621 and 627 (concluding that the different threshold requirements for the existence of an armed conflict under common Article 3 of the Geneva Conventions of 1949 and Additional Protocol II had both been fulfilled with respect to the conflict between the RPF and the Rwandan governmental forces). For a critical discussion, see generally S Darcy, Judges, Law and War: The Judicial Development of International Humanitarian Law (Cambridge University Press 2014) 109-10; and L van den Herik, The Contribution of the Rwandan Tribunal to the Development of International Law (Martinus Nijhoff Publishers 2005) 216-20 and 226-7. 
against civilians, typically in the context of genocide, could be characterized as closely related to the non-international armed conflict in Rwanda. ${ }^{101}$ As Larissa van den Herik has observed, this question 'goes to the heart of the qualification of what happened in Rwanda in 1994 and how the genocide and armed conflict are interrelated', ${ }^{102}$ bringing within the narrative frame of the tribunal the further questions of whether the genocide originated in the civil war, and whether, once it had begun, the genocide was part of the civil war or a separate event. ${ }^{103}$ Over time, the ICTR's approach to the nexus requirement evolved, with attendant consequences for its depiction of the relationship between the armed conflict and genocide.

Initially, Trial Chambers at the ICTR adopted a stringent approach to the nexus requirement. ${ }^{104}$ The strictness of the tribunal's approach was evident in two respects.

First, the Trial Chamber in Akayesu required a nexus not only between the crime and the conflict, but also between the defendant and a party to the conflict. In what became known as the 'public agent test', ${ }^{105}$ the Trial Chamber required the ICTR Prosecutor to prove that the defendant 'was either a member of the armed forces under the military command of either of the belligerent parties, or that he was legitimately mandated and expected, as a public official or agent or person otherwise holding public authority or de facto representing the Government, to support or fulfil the war efforts'. ${ }^{106}$

Second, the Trial Chamber in Kayishema and Ruzindana asserted that although the armed conflict 'had been used as a pretext to unleash an official policy of genocide', such a pretext was insufficient to establish a nexus between the genocidal acts of the accused and the armed conflict between the RAF and RPF. ${ }^{107}$ As the Trial Chamber argued, 'men, women and children were killed not as a result of the military operations between the [RAF] and the RPF but because of the policy of extermination of the Tutsi, pursued by

101 A Cassese, 'The Nexus Requirement for War Crimes' (2012) 10 JICJ 1395, 1407. On the 'closely related to' nexus standard, see Prosecutor v Duško Tadić, Case No IT-94-I-AR72, ICTY Appeals Chamber, Decision on the Defence Motion for Interlocutory Appeal on Jurisdiction (2 October 1995) at para 70; and Prosecutor v Georges Anderson Nderubumwe Rutaganda, Case No ICTR-96-3-T, ICTR Trial Chamber, Judgment and Sentence (6 December 1999) at para 104. For further elaboration of the nexus requirement, see Prosecutor v Kunarac et al., Case No IT-96-23 and IT-96-23/1-A, ICTY Appeals Chamber, Judgement (12 June 2002) at paras 57-59.

${ }^{102} \mathrm{~L}$ van den Herik, 'A Quest for Jurisdiction and an Appropriate Definition of Crime: Mpambara before the Dutch Courts' (2009) 7 JICJ 1117, 1125.

103 van den Herik (n 100) 228-9.

104 See similarly, Cassese (n 101) 1407 ('initially tepid approach'); H van der Wilt, 'War Crimes and the Requirement of a Nexus with an Armed Conflict' (2012) 10 JICJ 1113, 1119 ('Initially, trial chambers of the ICTR [...] were quite reluctant to accept a nexus between crimes and the armed conflict.'); and van den Herik (n 100) 235 ('high threshold set by the ICTR Chambers').

105 Cassese (n 101) 1408.

106 Akayesu (n 42) at para 640. See similarly, Rutaganda (n 101) at para 98; and Prosecutor v Alfred Musema, Case No ICTR-96-13-A, ICTR Trial Chamber, Judgement and Sentence (27 January 2000) at paras 264-275 and 280.

107 Kayishema and Ruzindana (n 42) at para 603. 
the official authorities of Rwanda'. ${ }^{108}$ Whilst these crimes were carried out 'during the armed conflict', they were committed 'as part of a distinct policy of genocide; they were committed parallel to, and not as a result of, the armed conflict'. ${ }^{109}$ This approach echoed the conclusions reached by the Trial Chamber in Akayesu, which had found that although the genocide "was probably facilitated by the conflict, in the sense that the fighting against the RPF forces was used as a pretext for the propaganda inciting genocide against the Tutsi', occurred 'concomitantly' with the conflict, and once underway 'became one of the stakes in the conflict' nonetheless the genocide 'was, evidently fundamentally different from the conflict'. ${ }^{110}$ As Antonio Cassese later observed, 'the logic here seems to suggest that the 'pretext' negates any true causal relationship between the conflict and the genocide'. ${ }^{111}$

The stringency of the nexus requirement in the ICTR's early case law led to a series of acquittals for war crimes and a historical narrative in which the genocide and civil war in Rwanda were clearly distinguished. ${ }^{112}$ However, this strict approach would soon give way to a more expansive application of the nexus requirement.

First, the Appeals Chamber in Akayesu dismissed the public agent test that had been applied by the Trial Chamber. Upon reviewing its Statute, Article 3 common to the Geneva Conventions, and the case law of the ICTY, the Appeals Chamber found no indication that individual criminal responsibility for war crimes was restricted to a particular class of perpetrators. ${ }^{113}$ As the Appeals Chamber explained, while 'in most cases, the perpetrator of the crime will probably have a special relationship with one party to the conflict $[\ldots]$ such a special relationship is not a condition precedent to the application of common Article 3 and, hence of Article 4 of the Statute'. ${ }^{114}$ The Chamber added that this conclusion was reinforced by the object and purpose of Article 3 common to the Geneva Conventions, which had been adopted primarily to ensure the protection of victims. ${ }^{115}$

Second, both Trial and Appeals Chambers gradually began to conflate the genocide and the armed conflict for the purpose of satisfying the nexus requirement. For instance, as part of its analysis to establish a nexus, the Trial Chamber in Bagosora expressly relied upon the fact that the armed conflict between the RAF and the RPF had 'both created the situation and provided a pretext for the extensive killings and other abuses of members of the civilian

\footnotetext{
108 ibid, para 619.

110 Akayesu (n 42) paras 127-128.

109 ibid, para 621 (emphasis added).

11 Cassese (n 101) 1410 (emphasis in original). 598-624; Musema (n 106) at paras 973-975; and Rutaganda (n 101) at paras 442-445.

113 Prosecutor v Jean-Paul Akayesu, Case No ICTR-96-4-A, ICTR Appeals Chamber, Judgment (1 June 2001) at paras 433-439. 114 ibid, para 444. 115 ibid, paras 440-444.
} 
population in Rwanda'. ${ }^{116}$ Other indicia relied upon by the Trial Chamber to establish the nexus included the substantial influence of military personnel in the manner in which the killings and other crimes had been executed, as well as the fact that the pretext for the killings at roadblocks had been to identify RPF infiltrators. ${ }^{117}$ Consequently, defendants were convicted for genocidal acts under the labels of both genocide and war crimes. ${ }^{118}$

The more lenient application of the nexus requirement facilitated convictions for war crimes, as well as the construction of a historical narrative in which the civil war and genocide were more closely intertwined. This turn in the jurisprudence also led to a divide in international criminal scholarship.

In support of the turn, Antonio Cassese claimed that the more lenient nexus requirement is more in line with the purpose of the law of war crimes to protect innocent people at times of armed conflict and also avoids 'the absurd outcome' that the planners of the genocide in Rwanda would avoid individual criminal responsibility for war crimes simply because they had 'used propaganda to incite civilians to engage in an "official policy" of genocide'. 119

Conversely, scholars such as Harman van der Wilt drew attention to the risk that lumping together genocide and war crimes in the Rwandan context 'might inadvertently add fuel to the génocidaires who had adduced the war as a pretext to kill Tutsis randomly'. ${ }^{120}$ Similarly, Larissa van den Herik warned that the emphasis of the lenient approach on the pretext of the perpetrators rather than their actual knowledge and intentions may unintentionally echo the Rwandan government's propaganda during the genocide, according to which all Tutsis were characterized as enemies. ${ }^{121}$ For van den Herik, only where individual Tutsis were selected for their suspected links with the RPF should the nexus requirement have been regarded as satisfied; ${ }^{22}$ reliance on the notion that the armed conflict provided a general pretext for the genocide should have been deemed insufficient since it placed undue reliance on government propaganda and failed to establish 'a real link to the armed conflict'. ${ }^{123}$

As this debate indicates, how the nexus requirement was interpreted affected both the likelihood of war crimes convictions and the type of narrative that was constructed about the relationship between the armed conflict and genocide in Rwanda. At the ICTR, in keeping with its victim-focused jurisprudence elsewhere, the judges gradually opted for a more lenient approach to the

116 Bagosora et al. (n 45) at para 2232. See similarly Prosecutor v Théoneste Bagosora and Anatole Nsengiyumva, Case No ICTR-98-41-A, ICTR Appeals Chamber, Judgement (14 December 2011) at para 405; and Ndindilyimana et al. (n 42) at para 266.

117 Bagosora et al. ( $\mathrm{n} 45)$ at paras 2233-2235. 118 ibid, paras 2228-2257.

119 Cassese (n 101) 1410-11.

121 van den Herik (n 100) 239.

122 ibid 256-257 (referring to the ICTR case of Ntagerura et al. as an example of a tribunal that applied this approach). 123 ibid 257. 
nexus requirement, resulting in a narrative in which the distinction between the armed conflict and genocide in Rwanda became increasingly blurred. ${ }^{124}$

\section{NARRATIVE PLURALISM BEYOND THE COURTROOM}

Even when international criminal courts manage to achieve inter-court and intra-court narrative consistency, the possibility remains for narrative pluralism beyond the courtroom. Narrative pluralism beyond the courtroom refers to the gap between the intended meaning of the historical narratives constructed within international criminal judgments and their public or social meaning within different audiences. ${ }^{125}$ In practice, the 'social relay' of judicially constructed narratives will typically vary depending on a range of factors, many of which are beyond the control of international criminal judges. ${ }^{126}$ As James Boyd White famously observed, 'whatever it may purport to say, what a judgment shall come to mean is a matter for the parties and their audience to address and decide'. ${ }^{127}$ Against this background, this section examines two sets of factors that have proven particularly influential in generating and maintaining narrative pluralism beyond the courtroom in practice. $^{128}$

124 ibid 257 (arguing that the more lenient approach to the nexus requirement 'fails to observe that the Tutsi within Rwanda cannot necessarily be equated with the RPF' and that 'it may be argued that the Rwanda Armed Forces (RAF) had two "war fronts", one against the RPF and the other against the Tutsi population in Rwanda').

125 See similarly RD Sloane, 'The Expressive Capacity of International Punishment: The Limits of the National Law Analogy and the Potential of International Criminal Law' (2007) 43 StanJIntlL 39,84 ('The expressive dimensions of punishment depend on its ability to convey the right meaning against the background of social norms, which vary significantly between the states, societies, cultures, and other constituencies that comprise the international community'); and DM Amann, 'Group Mentality, Expressivism, and Genocide' (2002) 2 IntCLR 93, 118 (focusing 'not on the intended meaning of a deed, but rather on the meaning that is understood by hearers, the public or social meaning').

126 F Mégret, 'Practices of Stigmatization' (2013) 76 LCPs 287, 311. See also C Stahn, 'Between 'Faith' and 'Facts': By What Standards Should We Assess International Criminal Justice?' (2012) 25 LIJL 251, 273 ('The acceptance and internalization of facts are processes that are shaped by other factors, such as media, inter-ethnic contact, or local politics.'); and JN Clark, 'The Impact Question: The ICTY and the Restoration and Maintenance of Peace' in B Swart et al. (eds), The Legacy of the International Criminal Tribunal for the Former Yugoslavia (Oxford University Press 2011) 55, 79 ('attitudes and behaviours are shaped and affected less by the work of a distant and poorlyunderstood tribunal than by a variety of far more immediate factors, including the media, levels of inter-ethnic contact, and whether a person has had positive experiences with members of other ethnic groups'.).

127 J Boyd White, Heracles' Bow: Essays on the Rhetoric and Poetics of the Law (University of Wisconsin Press 1985) 185 (emphasis added).

128 This section builds on material first articulated in B Sander, 'International Criminal Justice as Progress: From Faith to Critique' in M Bergsmo et al. (eds), Historical Origins of International Criminal Law: Volume 4 (Torkel Opsahl Academic EPublisher 2015) 749, 809-11; and B Sander, 'The Expressive Limits of International Criminal Justice: Victim Trauma and Local Culture in the Iron Cage of the Law' 5 European Society of International Law Conference Paper Series (2015) 5-6. 


\section{A. Social Psychological Factors}

First, the reception of narratives constructed within international criminal judgments will typically vary based on a range of social psychological factors. ${ }^{129}$ One of the most important insights of social psychology is that human decision making is not fundamentally rational, but driven by a range of motivational and cognitive biases that influence how we perceive the world and ourselves. ${ }^{130}$ Motivational biases occur when human reasoning is influenced by a desire to achieve a particular result. ${ }^{131}$ For example, according to self-defensive reasoning, individuals tend to be motivated to dismiss information that threatens their sense of self. ${ }^{132}$ Cognitive biases occur when human reasoning fails to live up to the rational ideal even where an individual's sole motivation is accuracy in decision-making. ${ }^{133}$ For instance, according to cognitive dissonance theory, when confronted with conflicting knowledge, opinions or beliefs about the environment, oneself or one's behaviour, humans tend to reduce the dissonance, as well as actively avoid situations and individuals that would likely increase it. ${ }^{134}$ Similarly, pursuant to confirmation bias theory, humans tend to seek, interpret and remember information in ways that are partial to existing beliefs and expectations. ${ }^{135}$ Confirmation bias can lead to a number of effects including: ${ }^{136}$ a propensity to attach greater weight to information acquired earlier in time (the primacy effect); a tendency for exposure to evidence that conflicts with one's beliefs to strengthen those beliefs (attitude polarization); and a propensity for a pre-existing belief to persist even after evidence supporting that belief has been comprehensively undermined (belief perseverance). Finally, pursuant to the theory of ingroup-outgroup bias, membership in a group can generate favouritism towards one's group (ingroup positivity) and dismissal or rejection of other groups (outgroup negativity). ${ }^{137}$ Group biases tend to be particularly intense when the group is classified or demarcated according to status or identity and in such a way as to provoke strong emotions. ${ }^{138}$

These social psychological factors have significant value in explaining why narratives constructed within international criminal judgments are often subject to diverse and conflicting interpretations amongst local audiences beyond the

129 See generally S Ford, 'A Social Psychology Model of the Perceived Legitimacy of International Criminal Courts: Implications for the Success of Transitional Justice Mechanisms', (2012) 45 VandJTransnatlL 405; M Milanović, 'Establishing the Facts about Mass Atrocities: Accounting for the Failure of the ICTY to Persuade Target Audiences' (2016) 47 GeoJIntlL 1321; and M Milanović, 'Courting Failure: When Are International Criminal Courts Likely to be Believed by Local Audiences?' in KJ Heller et al. (eds), The Oxford Handbook of International Criminal Law (Oxford University Press, Oxford, forthcoming). $\quad{ }^{130}$ Ford (n 129) 419.

131 ibid 419-420. 132 ibid 423. 133 ibid 419.

134 L Festinger, $A$ Theory of Cognitive Dissonance (reprint edn [1957] Stanford University Press 1962 ) $3 . \quad{ }_{135}$ Ford (n 129) $434 . \quad 136$ ibid 436-7.

137 Milanović, 'Establishing the Facts about Mass Atrocities' (n 129) 1340-1.

138 ibid 1341 . 
courtroom. In the aftermath of episodes of mass violence, it is not uncommon for local groups to maintain strong connections with particular factions to the underlying conflict. ${ }^{139}$ Moreover, in many cases, these local groups will possess deeply entrenched internal narratives about the conflict, typically encompassing not only an evasion of responsibility for any crimes committed by the faction with which they identify, but also a cloak of collective victimhood whereby each group views itself as the principal victim of wrongs committed by other groups during the conflict. ${ }^{140}$

Two implications generally follow from this state of affairs. First, members of local communities torn apart by conflict are likely to interpret the historical narratives constructed within international criminal judgments against the background of their communal attachments and self-serving narratives of collective victimhood. ${ }^{141}$ As such, the reception of judicially constructed narratives amongst local audiences will typically be subject to confirmation bias, including the tendency to prioritize information about the conflict received prior to the delivery an international criminal judgment as well as the preservation of their already entrenched beliefs. ${ }^{142}$

Second, local audiences are also likely to view the individuals prosecuted by international criminal courts less in their individual capacity than as symbols for the political and ideological programmes they developed and as representatives of the communities and State to which they belong. ${ }^{143}$ In these circumstances, the determination of the criminal responsibility of an individual in an international criminal judgment will often be interpreted by local audiences as a verdict on the responsibility of the community and group to which that individual belongs. ${ }^{144}$ As a result, the conviction of an individual will often cause cognitive dissonance amongst members of that individual's faction, who will view the conviction as an attack on their social identity and reject both the court's attribution of responsibility to the defendant as well as the broader historical narrative set out in the judgment. ${ }^{145}$

139 Ford (n 129) 459.

140 ibid 459-461; Milanović, 'Establishing the Facts about Mass Atrocities' (n 129) 1343-4 and 1347-52; Stover (n 20) 143; M Ignatieff, ‘Articles of Faith' 25 Index on Censorship (1996) 110, 116.

141 LE Fletcher and HM Weinstein, 'Violence and Social Repair: Rethinking the Contribution of Justice to Reconciliation' (2002) 24 HumRtsQ 573, 588.

142 Milanović 'Establishing the Facts about Mass Atrocities' (n 129) 1343-4 and 1347-52; Stover (n 20) 1343.

143 Koskenniemi (n 33) 16.

144 F Mégret, 'What Sort of Global Justice Is 'International Criminal Justice'?' (2015) 13 JICJ 77, 90.

145 This has been confirmed by a range of empirical studies. See, for example, Ford (n 129) at 426-33 (explaining the effect of cognitive dissonance on ethnic Serbians with respect to indictments and convictions at the ICTY); JN Clark, 'The ICTY and Reconciliation in Croatia: A Case Study of Vukovar' 10 JICJ (2012) 397, 414 (qualitative empirical study in Croatia); Clark (n 126) 77 (qualitative empirical study in Bosnia-Herzegovina); and LE Fletcher and HM Weinstein, 'A World unto Itself? The Application of International Justice in the Former Yugoslavia' in E Stover and HM Weinstein (eds), My Neighbour, My Enemy: Justice and Community in the Aftermath of Mass Atrocity (Cambridge University Press 2004) 29, 44 (qualitative empirical study of 32 judges and prosecutors with primary or appellate jurisdiction for national war crimes 
Of course, mass atrocity situations and their aftermath are far from uniform and in practice the intensity of motivational and cognitive biases will vary depending on the context in question. ${ }^{146}$ In this regard, it is apposite to also consider a range of practical factors that have influenced how judicially constructed narratives have been received within audiences beyond the courtroom.

\section{B. Practical Factors}

In terms of practical factors that influence narrative reception, it is important to recognize that in some instances judicially constructed narratives fail to reach their target audiences at all. ${ }^{147}$ In other instances, narratives constructed within international criminal judgments are first filtered through international and/or local carrier groups before reaching local communities. ${ }^{148}$

For the general public, international criminal proceedings can be alienating experiences. As Richard Wilson has observed, international criminal trials have a tendency to seem 'overly complex, excessively technical, and obsessed with minor procedural details'. 149 This perspective tallies with the views of journalists, such as Rebecca West, who famously characterized the International Military Tribunal at Nuremberg as 'a citadel of boredom'. ${ }^{150}$ The complexity of trial proceedings can alienate local communities as well as those directly participating in the trial as victims or witnesses, who may feel overwhelmed by the intricacies of criminal law procedure. ${ }^{151}$ Feelings of alienation can also be exacerbated by the complexity and general inaccessibility of international criminal judgments. ${ }^{152}$ One need only point to the trial judgment in the case against Charles Taylor at the Special Court for Sierra Leone (SCSL), ${ }^{153}$ which runs to 2,500 pages, to appreciate the improbability that such judgments will be read by members of the general public. ${ }^{154}$

trials in three areas of Bosnia-Herzegovina). See also M Milanović, 'The Impact of the ICTY on the Former Yugoslavia: An Anticipatory Postmortem' (2016) 110 AJIL 233.

146 See, in this regard, Ford (n 129) 463-75 (arguing that in some contexts the accumulation of evidence by international criminal courts can contribute to 'tipping points' that will lead individuals to revise their initial beliefs).

148 N Henry, War and Rape: Law, Memory and Justice (Routledge 2011) 119-22.

149 RA Wilson, Writing History in International Criminal Tribunals (Cambridge University Press 2011) 11. ${ }^{150} \mathrm{R}$ West, A Train of Powder (Viking Press 1955) 3.

151 See similarly, G Frankenberg, 'Human Rights and the Belief in a Just World' 12 I-CON (2014) 35, 55 (noting, in the field of human rights, that '[u]nless they're able to command a modicum of legal training or a pathologically robust psyche or both, claimants will hardly be able to avoid feeling dispossessed of what had once been their conflict - a feeling that may very well be described as alienation').

152 See, for example, Clark (n 145) 409 (noting that 'not everyone has access to the internet' and 'ordinary people cannot be expected to read long and complex legal documents').

${ }_{153}$ Taylor (n 93).

154 See similarly Gaynor (n 53) 1274-5 (noting that 'length is not necessarily undesirable in a document describing massive criminal activity', but adding that '[w] hat matters to the public, it appears, is $[\ldots]$ clarity and readability'). 
As a result, carrier groups have often played a significant role in influencing the social relay of narratives constructed within international criminal judgments. ${ }^{155}$ For several international criminal courts, the importance of carrier groups has often been heightened by their geographical, cultural and linguistic remoteness from local audiences. ${ }^{156}$ In such circumstances, national politicians and local media outlets have often proven particularly influential in shaping how judicially constructed narratives are received by local audiences in practice. ${ }^{157}$

A clear illustration of this tendency is identifiable in the reactions of several high-ranking politicians and local media outlets to the initial convictions of Croatian Generals Ante Gotovina and Mladen Markač for their involvement in Operation Storm during the Balkans war. ${ }^{158}$ At the time the convictions were rendered by the ICTY Trial Chamber, then Prime Minister Jadranka Kosor, as well as President Ivo Jasipović, each addressed a large crowd of Croatians at the annual celebrations of the Dan Pobjede, Zahvalnosti $i$ Hrvatskih Branitelja (Day of Victory, Thanksgiving and the Croatian Defenders). The Prime Minister expressly celebrated Gotovina and Markač, whilst the President declared that Operation Storm was the "crown of the struggle for a free Croatia'. ${ }^{159}$ Local media coverage of the convictions was similar, with one military history magazine containing only pro-Gotovina and anti-ICTY articles, including one that claimed that Operation Storm was 'a liberating operation and not a criminal enterprise'. ${ }^{160}$ As Janine Clarke has argued, these examples 'strongly attest to the fact that Croatia's politicians have played a major role in shaping popular attitudes towards the ICTY and its judgments'. ${ }^{161}$

Importantly, these practical factors will also affect the intensity of motivational and cognitive biases in the aftermath of mass atrocity situations. According to Marko Milanović, for example, the primary factor that influences the intensity of identity-protective reasoning within local

155 See generally, Milanović Establishing the Facts about Mass Atrocities (n 129) 1330-1336.

156 See, for example, JN Clark, 'From Negative to Positive Peace: The Case of Bosnia and Hercegovina' (2009) 8 Journal of Human Rights 360, 374 ('As a Tribunal that is geographically removed from the former Yugoslavia, that does not operate in the local languages of Bosnian/ Croatian/Serbian, and that leans towards the unfamiliar adversarial common law system, the ICTY was always going to struggle to reach out to and engage local people.').

157 See, for example, E Ramulić, 'Victims' Perspectives' in RH Steinberg (ed), Assessing the Legacy of the ICTY (Martinus Nijhoff Publishers 2011) 103, 105; R Hodžić, 'A Long Road Yet to Reconciliation: The Impact of the ICTY on Reconciliation and Victims' Perceptions of Criminal Justice' in RH Steinberg (ed), Assessing the Legacy of the ICTY (Martinus Nijhoff Publishers 2011) 115, 117; and M Klarin, 'The Impact of the ICTY Trials on Public Opinion in the Former Yugoslavia’ (2009) 7 JICJ 89, 90.

158 For discussion of Croatian reactions to the subsequent acquittal of the Generals on appeal, see JN Clark, 'Courting Controversy: The ICTY's Acquittal of Croatian Generals Gotovina and Markač' (2013) 11 JICJ 399, 419-420.

159 Clark (n 145) 417. 160 ibid 418.

161 ibid 417. See similarly Ford (n 129) 432 (referring to an 'echo chamber' effect, whereby the initial negative perceptions of the ICTY by the general Croat population are 'reflected back by associates and elites'). 
communities is the role of dominant political, intellectual and media elites. According to this perspective, narrative pluralism beyond the courtroom is likely to be exacerbated where group cohesion and polarization is maintained in the aftermath of a conflict, the elites of the groups in question are the same or substantially similar to those in power when the atrocities occurred, the postconflict society is characterized by an authoritarian absence of pluralism, and the elites in question perceive the work of the international criminal court as a threat to their own power and authority. ${ }^{162}$

As this brief perusal of social psychological and practical factors reveals, judicially constructed narratives are neither self-validating nor static but subject to an ongoing process of interpretation and contestation within audiences beyond the courtroom. As a result, rather than a bulwark against denialism, it is more common for both the authority and interpretation of historical narratives within international criminal judgments to remain disputed long after their initial construction. ${ }^{163}$

\section{CONCLUSION}

International criminal courts construct historical narratives about the culpability of individual defendants and the mass atrocity contexts within which they once operated. Yet, despite expectations of establishing historical closure, this article has demonstrated how the narratives constructed within international criminal judgments have often been subject to a process of ongoing contestation both within and beyond the courtroom. By way of conclusion, it is suggested that two implications follow from the narrative pluralism illuminated in this article.

First, against the dominant assumption in the field that international criminal judgments merely reflect truth, ${ }^{164}$ the narrative pluralism that arises within the courtroom serves to illustrate the constructed nature of the historical narratives rendered by international criminal courts. Any attempt to narrate history will always be based on assumptions and choices that are far from mechanical. ${ }^{165}$

162 Milanović, 'Courting Failure' (n 129).

163 D Luban, 'Demystifying Political Violence: Some Bequests of ICTY and ICTR' (2016) 110 AJIL Unbound 251, 254 (arguing that while international criminal courts may help fight denialism amongst global audiences, they are unlikely to succeed within the affected populations. As a result, we should 'think globally, hope locally - but don't be surprised if trying to establish the truth locally fails in the face of ongoing identity politics').

${ }^{164}$ See similarly JE Alvarez, 'Crimes of Hate/Crimes of State: Lessons from Rwanda' (1999) 24 YaleJIntlL 365, 448 (referring to 'the assumptions of many international lawyers that international trials only reflect truth but do not construct it').

165 T Skouteris, 'Engaging History in International Law' in JM Beneyto and D Kennedy (eds), New Approaches to International Law (TMC Asser Press 2012) 99, 104. See also Osiel (n 6) 272 (noting that history is always embedded 'within a normative framework governing the inclusion and exclusion of particular facts and the connections between them'); and H White, 'The Historical Text as Literary Artifact' in H White, Tropics of Discourse: Essays in Cultural Criticism (Johns Hopkins University Press 1978) 81, 84 (noting that facts are transformed into narratives 'by the suppression or subordination of certain of them and the highlighting of others, by characterization, motific repetition, variation of tone and point of view, alternative descriptive strategies, and the like'). 
As such, rather than the result of neutral acts of deduction, judicial narratives inevitably depend on the choices made by the multiplicity of actors who interact within international criminal proceedings. These choices include decisions concerning the scope and content of a court's jurisdictional framework, the ability of the prosecution and defence teams to access evidence, prosecutorial charging policies, the procedural and evidential framework relied upon to admit, scrutinize and evaluate evidence, and the interpretation of substantive legal categories. From this perspective, it is important to acknowledge that the historical narratives constructed within international criminal judgments will always be restricted and shaped by the institutional contexts within which they are rendered. ${ }^{166}$

At the same time, to recognize the constructed nature of historical narratives is not to be equated with the idea that there are no criteria available for judging their plausibility. ${ }^{167}$ Critical historians have readily acknowledged that it is possible to distinguish between good and bad historiography on the basis of criteria such as responsibility to the rules of evidence, fidelity to the factual record, logical consistency, coherence of argumentation, and depth of narrative detail. ${ }^{168}$ Equally, however, critical historians have also sought to emphasize that what counts as an adequate representation of a historical phenomenon must be adjudged to be relative to the time, place and context of its formulation. ${ }^{169}$ As such, a central concern for critical historians has been to

166 S Löytömäki, 'Legalisation of the Memory of the Algerian War in France' (2005) 7 Journal of the History of International Law 157, 177.

167 See similarly K Jenkins, Refiguring History: New Thoughts on an Old Discipline (Routledge 2003) 13 (noting that the critical perspective of history does not lead to the conclusion that 'we must therefore accept that everyone else's discursive "reality" and historical constructs are all equally correct or all equally wrong'. For, 'although there is no ultimate, objective foundation for our historical positions (or our moral decisions), we do still make decisions on the basis of preferences according to the tools at hand in any given social formation, we do still put worlds under descriptions, and we are still able to give (relative to such descriptions) argumentative support for them to those who might decide to listen to it and engage in conversation.').

168 White (n 165) 97; H White, The Content of the Form: Narrative Discourse and Historical Representation (Johns Hopkins University Press 1990) 4-5 and 78; H White, 'Historical Emplotment and the Problem of Truth' in S Friedlander (ed), Probing the Limits of Representation: Nazism and the "Final Solution" (Harvard University Press 1992) 37, 38. See similarly, Löytömäki (n 166) 177 (noting that '[t]here certainly do exist more or less plausible accounts of past events which can be evaluated by a community of scholarly historians'); and A Funkenstein, 'History, Counterhistory, and Narrative' in S Friedlander (ed), Probing the Limits of Representation: Nazism and the "Final Solution" (Harvard University Press 1992) 66, 79 (noting that while no historiographical endeavour may presume to 'represent' reality, this does not mean that the construction of narratives is arbitrary: 'If the narrative is true, reality, whatever its definition, must "shine through it" like Heidegger's being - and, like the latter, without ever appearing directly.').

169 H White, 'Response to Arthur Marwick' (1995) 30 JContempHist 233, 244. See also Löytömäki (n 166) 177 (noting that history has become 'an interpretation subject to time, place, and the point of view of the interpreter'); and White (n 165) 91 (noting how 'histories ought never to be read as unambiguous signs of the events they report, but rather as symbolic structures, extended metaphors, that "liken" the events reported in them to some form with which we have already become familiar in our literary culture'). 
illuminate the constructed nature of historical narratives and to deconstruct the biases and presuppositions on which such constructions are based. ${ }^{170}$ From this perspective, the narrative pluralism that arises within international criminal courts illustrates the importance of developing a critical awareness of the practices and actors that shape how history is constructed within particular institutional contexts.

Second, the narrative pluralism illuminated in this article also demonstrates a need for humbling the expectations that have typically been placed on international criminal courts both with respect to the construction of narratives within the courtroom and their reception beyond it.

Within the courtroom, while consistency in the interpretation of legal and evidentiary frameworks is important for ensuring fairness towards the accused, ${ }^{171}$ a degree of narrative pluralism is likely to be unavoidable. In particular, narrative pluralism is likely to arise from even slight variations in the evidentiary, charging and interpretative decisions of the different actors who interact in each new case. In addition, a unique historical perspective is almost inevitable when viewing similar mass atrocity incidents through the prism of determining the culpability of different accused individuals. Importantly, a degree of narrative pluralism need not necessarily be a cause for concern. In fact, narrative pluralism can even serve to enrich the historical record of an international criminal court. ${ }^{172}$ With this in mind, rather than aspiring for international criminal courts to deliver improbable moments of historical closure, it is suggested that the entire international criminal process from its inception to the storage of records in the court archives should be viewed in more modest terms as a discursive beginning for the examination of particular episodes of mass violence. ${ }^{173}$

${ }^{170} \mathrm{H}$ White, 'Postmodernism and Textual Anxieties' in B Strath and N Witoszek (eds), The Postmodern Challenge: Perspectives East and West (Rodopi BV 1999) 27, 38 ('The important distinction from a post-modernist point of view is not between ideology and objectivity but between ideological constructions of history that are more or less open about the "constructed" nature of their versions of history and more or less willing to make of their own modes of production elements of their contents. [...] If postmodern notions of history are informed by a critique of the ideology of objectivism, this does not necessarily mean that they are opposed to the truth and committed to lie, delusion, fantasy, or fiction. It means rather that [...] postmodernism recognizes that "reality" is always as much constructed in discourse as it is discovered in the historical record. Which means that post-modernist "objectivity" is aware of its own constructed nature and makes this work of construction the subject of its discourse.').

171 See generally M Cupido, 'Facing Facts in International Criminal Law: A Casuistic Model of Judicial Reasoning' (2016) 14 JICJ 1.

172 Douglas (n 16) 198-9 ('Particularly in the case of traumatic or sensational history, it seems the law often only reaches a satisfactory result and understanding through a process of revisiting and retrying the contested events.').

${ }^{173}$ In this vein, it is welcome that the Outcome Document of the ICTY Legacy Dialogues Conference recently concluded that the historical value of court records 'extends beyond judgments', requires a comparison of 'findings and testimony across cases', and that 'a fuller picture may emerge through complementarity of courts and other justice mechanisms'. See 'Outcome of the ICTY Legacy Dialogues Conference: Conclusions and Recommendations' (2224 June 2017) Sarajevo, Bosnia and Herzegovina, 7. 
Beyond the courtroom, international criminal courts undoubtedly have the potential to ignite public discourse, ${ }^{174}$ stimulate social awakening, ${ }^{175}$ and initiate civilized debate on what has happened during a particular mass atrocity situation. ${ }^{176}$ However, it is important to recognize that whether this potential is fulfilled in practice will almost entirely depend upon factors beyond the control of international criminal courts, including most prominently the reaction of local elites. ${ }^{177}$

At a minimum, therefore, it is suggested that doing justice to history through the medium of international criminal prosecutions requires a sobering of the narrative expectations that have traditionally been placed on international criminal courts. ${ }^{178}$

174 See, for example, Landsman (n 24) 111 (noting, with regard to the Eichmann trial, that '[w] hether it was the key to the ignition of public discourse is open to question, but that it significantly contributed to the movement in that direction seems beyond serious doubt').

175 See, for example, J O'Connell, 'Gambling with the Psyche: Does Prosecuting Human Rights Violators Console Their Victims?' (2005) 46 HarvIntlLJ 295, 232 (discussing trials as 'stimulants of social awakening').

176 See generally Osiel (n 6) 36-55 and 283-301.

177 Milanović, 'Courting Failure' (n 129) 37 ('by themselves international criminal tribunals have little, if any, power to shape local public opinion. In other words, their relative success or failure in gaining acceptance for their findings among target audiences is not really their success or failure') (emphasis in original).

${ }^{178}$ On the importance of modesty within the field of international criminal justice, see generally Sander, 'International Criminal Justice as Progress' (n 128); DS Koller, 'The Faith of the International Criminal Lawyer' (2008) 40 NYUJIntlLaw\&Pol 1019; S Kendall and SMH Nouwen, 'Speaking of Legacy: Toward an Ethos of Modesty at the International Criminal Tribunal for Rwanda' (2016) 110 AJIL 212; and L van den Herik, 'International Criminal Law as a Spotlight and Black Holes as Constituents of Legacy’ (2016) 110 AJIL Unbound 209. See also S Moyn, 'On a Self-Deconstructing Symposium' (2016) AJIL Unbound 258, 262 (pointing to 'the intuition that what people need is not exactly a legacy monument for the ICTY or the ICTR so much as a reality check about what it might actually take to improve a recalcitrant and violent world'). 